\title{
Estimation of the dietary exposure associated with pesticide residues in vegetables grown under covers in 2010-2012
}

\author{
Oszacowanie narażenia konsumentów związane \\ z występowaniem pozostałości środków ochrony roślin \\ w warzywach uprawianych pod osłonami w latach 2010-2012
}

\author{
Magdalena Podbielska, Ewa Szpyrka, Aneta Matyaszek, \\ Anna Kurdziel, Julian Rupar, Magdalena Słowik-Borowiec
}

\begin{abstract}
Summary
The aim of this work was to assess the actual level of pesticide intake along with the eaten vegetables grown under covers: tomatoes, cucumbers, sweet peppers and early vegetables - radishes, lettuce, in 2010-2012, as well as a dietary risk assessment to the consumers affected by short-term and long-term exposure. A total of 74 samples of vegetables grown under cover were analysed. Pesticide residues were detected in 26 samples (35\% of analysed samples). The calculations of the long and short term exposures revealed that vegetables grown under cover could be consumed, both by toddlers and by adults without any adverse health effects.
\end{abstract}

Key words: dietary exposure, pesticide residues, vegetables under covers

\section{Streszczenie}

Celem pracy było oszacowanie rzeczywistego pobrania pestycydów wraz ze spożywanymi w latach 2010-2012 warzywami uprawianymi pod osłonami: pomidorami, ogórkami, papryką, oraz nowalijkami - rzodkiewką, sałatą i dokonywanie na tej podstawie oceny ryzyka dla konsumentów związanego z narażeniem krótkoterminowym i długoterminowym. Oznaczono pozostałości środków ochrony roślin w 74 próbkach warzyw uprawianych pod osłonami. W 26 badanych próbkach stwierdzono pozostałości środków ochrony roślin, co stanowiło $35 \%$ wszystkich próbek. Obliczenia narażenia długo- i krótkoterminowego wykazały, że warzywa uprawiane pod osłonami mogą być spożywane zarówno przez małe dzieci oraz przez dorosłych bez powodowania niekorzystnych skutków zdrowotnych.

Słowa kluczowe: narażenie, pozostałości pestycydów, warzywa pod osłonami

Instytut Ochrony Roślin - Państwowy Instytut Badawczy

Terenowa Stacja Doświadczalna

Langiewicza 28, 35-101 Rzeszów

M.Podbielska@iorpib.poznan.pl 


\section{Wstęp / Introduction}

W Polsce uprawa warzyw pod osłonami stanowi 14\% ogólnych zbiorów warzyw. Powierzchnia upraw warzyw w 2010 roku w szklarniach wyniosła 18528 tys. $\mathrm{m}^{2}$, w inspektach 154 tys. $\mathrm{m}^{2}$, w tunelach foliowych 30224 tys. $\mathrm{m}^{2}$, a zbiory $\mathrm{z}$ upraw wyniosły 689 tys. ton (GUS 2011). Uprawia się przede wszystkim pomidory, ogórki, paprykę oraz nowalijki, takie jak: rzodkiewka, sałata. Osłony stwarzają możliwości uprawy różnych gatunków warzyw, jako przedplony, plon główny i poplony. Zapewniając roślinom odpowiednie możliwości wzrostu, muszą panować w nich dogodne warunki temperatury, wilgotności i nasłonecznienia.

W uprawie pod osłonami istnieje wiele problemów związanych $\mathrm{z}$ występowaniem chorób pochodzenia infekcyjnego (grzybowego, bakteryjnego, wirusowego). Kompleksowa ochrona polega na ograniczaniu bądź hamowaniu rozwoju chorób przez zastosowanie metod agrotechnicznych, fizycznych, biologicznych, a także chemicznych wykorzystując dopuszczone do stosowania środki ochrony. Substancje chemiczne zapewniają ochronę przed agrofagami, ale obok korzyści, jakie wynikają z ich zastosowania $\mathrm{w}$ rolnictwie mogą mieć one jednocześnie negatywny wpływ na zdrowie ludzi poprzez zanieczyszczenie żywności.

Potrzeba badania pozostałości chemicznych środków ochrony roślin (ś.o.r.) w żywności pochodzenia roślinnego wynika z ich toksycznego działania na organizm człowieka oraz powszechności stosowania w rolnictwie. Badania mają szczególne znaczenie dla oceny narażenia ludności na pozostałości pestycydów w produktach spożywczych, ponieważ pozwalają na wskazanie tych substancji czynnych (s.cz.), które występują w największych ilościach w żywności oraz tych produktów spożywczych, które najczęściej zawierają ich pozostałości (Góralczyk i wsp. 1998).

Obowiązująca w Unii Europejskiej strategia bezpieczeństwa żywności pochodzenia roślinnego nakłada na państwa członkowskie obowiązek prowadzenia programów monitoringu i urzędowej kontroli żywności pod kątem zanieczyszczeń, w tym pozostałości ś.o.r. Dodatkowym celem prowadzonej kontroli jest oszacowanie rzeczywistego pobrania pestycydów i dokonywanie na tej podstawie oceny ryzyka dla konsumentów związanego z narażeniem krótkoterminowym (ostrym) i długoterminowym (przewlekłym) (Kostka i wsp. 2011).

W pracy przedstawiono wyniki oszacowania rzeczywistego pobrania pestycydów wraz ze spożywanymi w latach 2010-2012 warzywami uprawianymi pod osłonami i dokonanie na tej podstawie oceny ryzyka dla konsumentów, związanego $\mathrm{z}$ narażeniem krótkoterminowym i długoterminowym.

\section{Materiały i metody / Materials and methods}

Materiał do badań stanowiły próbki warzyw uprawianych pod osłonami: ogórki, pomidory, sałata, rzodkiewka, papryka oraz cebula zielona. W latach 2010-2012, w Laboratorium Badania Pozostałości Środków Ochrony
Roślin Terenowej Stacji Doświadczalnej Instytutu Ochrony Roślin - Państwowego Instytutu Badawczego w Rzeszowie (laboratorium) poddano kontroli łącznie 74 próbki. Analizy wykonywane były w ramach urzędowej kontroli zlecanej przez Ministerstwo Rolnictwa i Rozwoju Wsi oraz na zlecenie producentów i firm zajmujących się przetwórstwem, skupem, eksportem warzyw. Próbki do badań w ramach urzędowej kontroli pobierane były w sposób losowy $\mathrm{z}$ miejsc produkcji rolniczej na obszarze południowo-wschodniej Polski przez inspektorów Państwowego Inspektoratu Ochrony Roślin i Nasiennictwa (Rozporządzenie 2007), zgodnie z harmonogramem opracowanym przez Główny Inspektorat Ochrony Roślin i Nasiennictwa. W przypadku indywidualnych zleceń, próbki dostarczane były przez producentów.

Pozostałości ś.o.r. oznaczano akredytowanymi według normy PN-EN ISO/IEC 17025 (2005), metodami analitycznymi, zgodnie z wymaganiami Komisji Europejskiej (Document SANCO 2011).

Pozostałości ditiokarbaminianów oznaczano metodą spektrofotometryczną (Chmiel 1979; Sadło i wsp. 2003). Pozostałe s.cz. oznaczane były metodą chromatografii gazowej $\mathrm{z}$ detekcją wychwytu elektronów oraz termojonowa (Grzegorzak i wsp. 2012). Uzyskane wyniki porównywano $\mathrm{z}$ najwyższymi dopuszczalnymi poziomami pozostałości (NDP) obowiązującymi w Polsce (Rozporządzenie 2005).

Laboratorium corocznie uczestniczy w międzynarodowych badaniach biegłości organizowanych przez Unię Europejską (University of Almeria, Hiszpania), a także w międzylaboratoryjnych badaniach porównawczych, w których uzyskuje poprawne wyniki. Dowodzi to, iż system kontroli poziomów pozostałości jest prawidłowy.

Do oszacowania pobrania pozostałości przez konsumentów wykorzystano nowe modele brytyjskiego Urzędu Bezpieczeństwa Pestycydów Ministerstwa ds. Środowiska, Żywności i Rolnictwa. Obliczeń dokonano wykorzystując oprogramowanie Chronic and Acute Consumer ver1.1. z wbudowanymi bazami danych spożycia dla 10 grup ludności (Pesticides Safety Directorate 2006).

Narażenie długoterminowe obliczano według wzoru:

$$
\mathrm{NEDI}=\sum \frac{\mathrm{F}_{\mathrm{i}} \times \mathrm{RL}_{\mathrm{i}} \times \mathrm{P}_{\mathrm{i}}}{\mathrm{mc}}
$$

NEDI - narodowe oszacowane dzienne pobranie,

$\mathrm{F}_{\mathrm{i}} \quad$ - spożycie produktu,

$\mathrm{RL}_{\mathrm{i}}$ - odpowiedni poziom pozostałości w produkcie,

$\mathrm{P}_{\mathrm{i}} \quad$ - współczynnik korekcyjny związany $\mathrm{z}$ obniżeniem lub podwyższeniem poziomów pozostałości w wyniku ich przechowywania lub przetwarzania,

mc - masa ciała.

Krótkoterminowe narażenie obliczano dla 2 przypadków, gdy:

1. Produkty, dla których dostępne dane pozostałości złożonych, odzwierciedlały ich poziom w spożywanym produkcie. Dzienne pobranie obliczano według poniższego wzoru:

$$
\mathrm{NESTI}=\sum \frac{(\mathrm{F} \times \text { HR.P })}{\mathrm{mc}}
$$


NESTI - narodowe oszacowane krótkoterminowe pobranie,

F $\quad$ - spożycie pełnej porcji dla jednostki produktu,

HR.P - najwyższy wykryty poziom pozostałości z wbudowanym współczynnikiem związanym z przetwarzaniem lub porcją jadalną. Jeżeli dostępne są dane związane $\mathrm{z}$ przetwarzaniem lub porcją jadalną należy stosować HR.P zamiast prostej najwyższej pozostałości,

mc - masa ciała.

2. Dostępne dane pozostałości złożonych nie odzwierciedlają poziomów pozostałości w produkcie ze względu na niejednorodny rozkład. Dzienne pobranie obliczano według wzoru:

$$
\mathrm{NESTI}=\sum \frac{(\mathrm{U} \times \mathrm{HR} . \mathrm{P} \times v)+(\{\mathrm{F}-\mathrm{U}\} \times \text { HR.P })}{\mathrm{mc}}
$$

U - masa pierwszej jednostki produktu. Jeżeli U jest większe od pełnej porcji (F), wtedy należy użyć poziomu spożycia nie wyższego od wartości $\mathrm{F}$ i zastosować tylko pierwszą część równania, a w nim F zamiast U,

$v$ - współczynnik niejednorodności.

Ryzyko zagrożenia zdrowia ludzi pozostałościami ś.o.r. powinno być szacowane, gdy żywność zawiera pozostałości pestycydów na poziomie wyższym niż obowiązujące NDP, gdy $\mathrm{w}$ danej uprawie wykrywane są niezalecane środki ochrony roślin lub można spodziewać się niekorzystnego wpływu pobranego środka na zdrowie ludzi (Łozowicka 2010).

Narażenie długo- i krótkoterminowe oszacowano dla tzw. populacji generalnej, w praktyce osób dorosłych o masie ciała $76 \mathrm{~kg}$ oraz grupy najbardziej wrażliwej na skutki narażenia na pozostałości ś.o.r., tzn. dzieci w wieku od 1,5 do 4 lat $(14,6 \mathrm{~kg})$. Obliczono je poprzez porównanie jednorazowego pobrania pozostałości ś.o.r. do wielkości odpowiednio ADI (Acceptable Daily Intake) lub ARfD (Acute Reference Dose). Za dopuszczalne, nie stwarzające zagrożeń dla zdrowia przyjmuje się wartości oszacowanego narażenia konsumentów na pozostałości ś.o.r. nie przekraczające $100 \%$ wartości ADI lub ARfD (Scientific Report of EFSA 2013).

Szacowanie narażenia oparto na danych dotyczących pozostałości ś.o.r. wykrytych podczas kontroli polskich płodów rolnych, przeprowadzonej $\mathrm{w}$ laboratorium oraz danych spożycia żywności - z braku danych polskich - w Wielkiej Brytanii.

\section{Wyniki i dyskusja / Results and discussion}

W laboratorium poddano kontroli łącznie 74 próbki. W 26 badanych próbkach stwierdzono pozostałości ś.o.r., co stanowiło 35\% wszystkich próbek. Najwięcej pozostałości ś.o.r. stwierdzono w cebuli zielonej $(50 \%$ badanych próbek tej uprawy), papryce (50\%) oraz

Tabela 1. Występowanie pozostałości ś.o.r. w warzywach uprawianych pod osłonami, w latach 2010-2012

Table 1. Pesticide residues in vegetables grown under covers, in 2010-2012

\begin{tabular}{|c|c|c|c|c|c|c|}
\hline \multirow{2}{*}{$\begin{array}{l}\text { Uprawa } \\
\text { Crop }\end{array}$} & \multirow{2}{*}{\begin{tabular}{|c|} 
Liczba \\
analizowanych \\
próbek \\
Number of \\
analysed samples
\end{tabular}} & \multirow{2}{*}{$\begin{array}{l}\text { Substancja czynna } \\
\text { Active substance }\end{array}$} & \multicolumn{2}{|c|}{$\begin{array}{l}\text { Próbki z pozostałościami } \\
\text { Samples with residues }\end{array}$} & \multirow{2}{*}{$\begin{array}{c}\text { Zakres } \\
\text { wykrywanych pozostałości } \\
\text { Range of detected residues } \\
\min -\max \\
{[\mathrm{mg} / \mathrm{kg}]}\end{array}$} & \multirow{2}{*}{$\begin{array}{c}\text { NDP } \\
\text { MRL } \\
{[\mathrm{mg} / \mathrm{kg}]}\end{array}$} \\
\hline & & & $\begin{array}{l}\text { liczba } \\
\text { number }\end{array}$ & {$[\%]$} & & \\
\hline $\begin{array}{l}\text { Ogórek } \\
\text { Cucumber }\end{array}$ & 23 & $\begin{array}{l}\text { azoxystrobine } \\
\text { bifenthrin } \\
\text { chlorothalonil }\end{array}$ & $\begin{array}{l}3 \\
2 \\
1\end{array}$ & $\begin{array}{c}13 \\
9 \\
4\end{array}$ & $\begin{array}{c}0,02-0,14 \\
0,02 \\
0,05\end{array}$ & $\begin{array}{c}1 \\
0,1 \\
1\end{array}$ \\
\hline $\begin{array}{l}\text { Pomidor } \\
\text { Tomato }\end{array}$ & 38 & $\begin{array}{l}\text { azoxystrobine } \\
\text { bifenthrin } \\
\text { boscalid } \\
\text { chlorothalonil } \\
\text { cyprodinil } \\
\text { dithiocarbamates } \\
\text { fludioxonil } \\
\text { iprodione }\end{array}$ & $\begin{array}{l}2 \\
3 \\
1 \\
6 \\
5 \\
6 \\
5 \\
2\end{array}$ & $\begin{array}{c}5,3 \\
7,9 \\
2,6 \\
15,8 \\
13,1 \\
15,8 \\
13,2 \\
5,3\end{array}$ & $\begin{array}{c}0,02-0,05 \\
0,03 \\
0,05 \\
0,01-0,09 \\
0,01-0,07 \\
0,03-0,95 \\
0,02-0,08 \\
0,19-0,24\end{array}$ & $\begin{array}{c}3 \\
0,2 \\
1 \\
2 \\
1 \\
3 \\
1 \\
5\end{array}$ \\
\hline $\begin{array}{l}\text { Sałata } \\
\text { Lettuce }\end{array}$ & 3 & - & - & - & - & - \\
\hline $\begin{array}{l}\text { Rzodkiewka } \\
\text { Radish }\end{array}$ & 2 & - & - & - & - & - \\
\hline $\begin{array}{l}\text { Papryka } \\
\text { Sweet pepper }\end{array}$ & 6 & $\begin{array}{l}\text { azoxystrobine } \\
\text { chloropyrifos } \\
\text { chlorothalonil } \\
\text { cypermethrin } \\
\text { iprodione }\end{array}$ & $\begin{array}{l}2 \\
1 \\
1 \\
1 \\
1\end{array}$ & $\begin{array}{l}33,3 \\
16,6 \\
16,6 \\
16,6 \\
16,6\end{array}$ & $\begin{array}{l}0,02 \\
0,09 \\
0,08 \\
0,02 \\
0,02\end{array}$ & $\begin{array}{c}3 \\
0,5 \\
2 \\
0,5 \\
5\end{array}$ \\
\hline $\begin{array}{l}\text { Zielona cebula } \\
\text { Green onion }\end{array}$ & 2 & $\begin{array}{l}\text { chloropyrifos } \\
\text { prometryn }\end{array}$ & $\begin{array}{l}1 \\
1\end{array}$ & $\begin{array}{l}100 \\
100\end{array}$ & $\begin{array}{l}0,01 \\
0,02\end{array}$ & $\begin{array}{c}0,2 \\
0,01\end{array}$ \\
\hline
\end{tabular}

NDP - najwyższy dopuszczalny poziom pozostałości - MRL - Maximum Residue Level 
Tabela 2. Oszacowanie narażenia długoterminowego na pozostałości ś.o.r. w warzywach uprawianych pod osłonami, w latach 2010-2012

Table 2. Assessment the chronic dietary exposure to pesticide residues in vegetables grown under covers, in 2010-2012

\begin{tabular}{|c|c|c|c|c|c|c|c|c|c|}
\hline \multirow{3}{*}{$\begin{array}{c}\text { Uprawa } \\
\text { Crop }\end{array}$} & \multirow{3}{*}{$\begin{array}{l}\text { Substancja } \\
\text { czynna } \\
\text { Active } \\
\text { substance }\end{array}$} & \multirow{3}{*}{\begin{tabular}{|} 
Średnia \\
pozostałość \\
Average \\
residue \\
level \\
{$[\mathrm{mg} / \mathrm{kg}]$}
\end{tabular}} & \multirow{3}{*}{$\mid \begin{array}{c}\text { ADI } \\
{[\mathrm{mg} / \mathrm{kg} \text { masy ciała }]} \\
{[\mathrm{mg} / \mathrm{kg} \text { body }} \\
\text { weight }]\end{array}$} & \multicolumn{2}{|c|}{$\begin{array}{c}\text { Wysoki poziom } \\
(97,5 \text { percentyl) } \\
\text { długoterminowego spożycia } \\
\text { High level (97.5 percentile) } \\
\text { of long term consumption }\end{array}$} & \multicolumn{4}{|c|}{ Pobranie - Intake } \\
\hline & & & & \multirow{2}{*}{$\begin{array}{c}\begin{array}{c}\text { dzieci } \\
\text { toddlers } \\
(14,5 \mathrm{~kg})\end{array} \\
{[\mathrm{kg} / \mathrm{osoba} /} \\
\text { dzień }] \\
{[\mathrm{kg} / \text { person/ }} \\
\text { day }]\end{array}$} & \multirow{2}{*}{$\begin{array}{c}\begin{array}{c}\text { dorośli } \\
\text { adults } \\
(76 \mathrm{~kg})\end{array} \\
\begin{array}{c}\mathrm{kg} / \mathrm{osoba} / \\
\text { dzień }]\end{array} \\
{\left[\begin{array}{c}\mathrm{kg} / \text { person/ } \\
\text { day }]\end{array}\right.} \\
\end{array}$} & \multicolumn{2}{|c|}{$\begin{array}{c}\text { dzieci } \\
\text { toddlers } \\
(14,5 \mathrm{~kg})\end{array}$} & \multicolumn{2}{|c|}{$\begin{array}{l}\text { dorośli } \\
\text { adults } \\
(76 \mathrm{~kg}) \\
\end{array}$} \\
\hline & & & & & & \begin{tabular}{|c|}
{$[\mathrm{mg} / \mathrm{kg} /$} \\
masy ciała $]$ \\
{$[\mathrm{mg} / \mathrm{kg}$} \\
body weight $]$ \\
\end{tabular} & $\% \mathrm{ADI}$ & $\begin{array}{c}{[\mathrm{mg} / \mathrm{kg} /} \\
\text { masy ciała }] \\
{[\mathrm{mg} / \mathrm{kg}} \\
\text { body weight }]\end{array}$ & $\% \mathrm{ADI}$ \\
\hline \multirow{3}{*}{$\begin{array}{l}\text { Ogórek } \\
\text { Cucumber }\end{array}$} & azoxystrobine & 0,08 & 0,2 & 0,0351 & 0,0309 & 0,00019 & 0,095 & 0,00003 & 0,015 \\
\hline & bifenthrin & 0,02 & 0,15 & 0,0351 & 0,0309 & 0,00005 & 0,033 & 0,00001 & 0,007 \\
\hline & chlorothalonil & 0,05 & 0,015 & 0,0351 & 0,0309 & 0,00012 & 0,800 & 0,00002 & 0,133 \\
\hline \multirow{8}{*}{$\begin{array}{l}\text { Pomidor } \\
\text { Tomato }\end{array}$} & azoxystrobine & 0,03 & 0,2 & 0,0382 & 0,1047 & 0,00008 & 0,040 & 0,00004 & 0,020 \\
\hline & bifenthrin & 0,03 & 0,15 & 0,0382 & 0,1047 & 0,00008 & 0,053 & 0,00004 & 0,026 \\
\hline & boscalid & 0,05 & 0,04 & 0,0382 & 0,1047 & 0,00013 & 0,325 & 0,00007 & 0,175 \\
\hline & chlorothalonil & 0,05 & 0,015 & 0,0382 & 0,1047 & 0,00013 & 0,867 & 0,00007 & 0,467 \\
\hline & cyprodinil & 0,04 & 0,03 & 0,0382 & 0,1047 & 0,00011 & 0,367 & 0,00006 & 0,200 \\
\hline & dithiocarbamates & 0,23 & 0,03 & 0,0382 & 0,1047 & 0,00061 & 2,033 & 0,00032 & 1,067 \\
\hline & fludioxonil & 0,04 & 0,37 & 0,0382 & 0,1047 & 0,00011 & 0,029 & 0,00006 & 0,016 \\
\hline & iprodione & 0,22 & 0,06 & 0,0382 & 0,1047 & 0,00030 & 0,500 & 0,00058 & 0,967 \\
\hline \multirow{5}{*}{$\begin{array}{l}\text { Papryka } \\
\text { Sweet } \\
\text { pepper }\end{array}$} & azoxystrobine & 0,02 & 0,2 & 0,0117 & 0,0281 & 0,00002 & 0,010 & 0,00001 & 0,005 \\
\hline & chlorpyrifos & 0,09 & 0,01 & 0,0117 & 0,0281 & 0,00007 & 0,700 & 0,00003 & 0,300 \\
\hline & chlorothalonil & 0,08 & 0,015 & 0,0117 & 0,0281 & 0,00006 & 0,400 & 0,00003 & 0,200 \\
\hline & cypermethrin & 0,02 & 0,05 & 0,0117 & 0,0281 & 0,00002 & 0,040 & 0,00001 & 0,020 \\
\hline & iprodione & 0,02 & 0,06 & 0,0117 & 0,0281 & 0,00002 & 0,033 & 0,00001 & 0,017 \\
\hline \multirow{2}{*}{$\begin{array}{l}\text { Zielona } \\
\text { cebula } \\
\text { Green } \\
\text { onion } \\
\end{array}$} & chlorpyrifos & 0,01 & 0,01 & 0,0023 & 0,0190 & 0,00001 & 0,100 & 0,00001 & 0,100 \\
\hline & prometryn & 0,02 & 0,01 & 0,0023 & 0,0190 & 0,00001 & 0,100 & 0,00001 & 0,100 \\
\hline $\begin{array}{l}\text { Suma } \\
\text { Sum }\end{array}$ & & & & & & & 6,525 & & 3,835 \\
\hline
\end{tabular}

ADI - akceptowalne dzienne pobranie - Acceptable Daily Intake

pomidorach (45\%). Najczęściej wykrywanymi s.cz. były pozostałości fungicydów: chlorotalonilu -8 próbek, azoksystrobiny - 7 próbek, ditiokarbaminianów - 6 próbek, cyprodinilu i fludioksonilu po 5 próbek oraz insektycydów: bifentryna - 4 próbki. W 9 próbkach stwierdzono występowanie pozostałości wielokrotnych. W 2 próbkach pomidora oraz w 1 próbce papryki wykryto pozostałości 4 s.cz., natomiast w 1 próbce pomidora stwierdzono pozostałości 3 s.cz. Szczegółowe dane zostały przedstawione w tabeli 1 .

Badania pozostałości ś.o.r. wykazały obecność substancji czynnych niezalecanych do ochrony danej uprawy - chlorotalonilu i chloropiryfosu, które wykryto w próbkach papryki i zielonej cebuli (Zalecenia 2010/2011, 2012/2013). Ponadto w próbce zielonej cebuli stwierdzono obecność prometryny, s.cz. zakazanej do stosowania $\mathrm{w}$ ochronie roślin, a także stwierdzono przekroczenie jej NDP. W przypadku pozostałości przekra- czających NDP oraz w przypadku zastosowania preparatów niedozwolonych wysyłano powiadomienia informacyjne w ramach systemu wczesnego ostrzegania o niebezpiecznych produktach żywnościowych i paszach RASFF (Rapid Alert System for Food and Feed).

Przedstawione wyniki wskazują, iż największą grupą związków wykrywanych w warzywach pod osłonami $\mathrm{z}$ terenu Polski południowo-wschodniej były fungicydy. Wyniki te korelują z danymi uzyskanymi dla Polski (Nowacka i wsp. 2011, 2012b). Wykryte s.cz. (chlorotalonil, azoksystrobina i ditiokarbaminiany) wchodzą w skład preparatów grzybobójczych wykazujących szerokie oddziaływanie na patogeny pochodzenia grzybowego. Stosuje się je do zwalczania mączniaków, szarej pleśni, alternariozy czy zarazy ziemniaków występującej na pomidorach, które są zagrożeniem upraw warzyw pod osłonami (Zalecenia 2010/2011, 2012/2013). Istotną rolę w zwalczaniu tych chorób odgrywają chemiczne metody 
Tabela 3. Oszacowanie narażenia krótkoterminowego na pozostałości ś.o.r. w warzywach uprawianych pod osłonami, w latach 2010-2012

Table 3. Estimation of the acute dietary exposure to pesticide residues in vegetables grown under covers, in 2010-2012

\begin{tabular}{|c|c|c|c|c|c|c|c|c|c|c|c|}
\hline \multirow{3}{*}{$\begin{array}{c}\text { Uprawa } \\
\text { Crop }\end{array}$} & \multirow{3}{*}{$\begin{array}{c}\text { Substancja } \\
\text { czynna } \\
\text { Active } \\
\text { substance }\end{array}$} & \multirow{3}{*}{$\begin{array}{c}\text { Najwyż- } \\
\text { szy } \\
\text { poziom } \\
\text { pozosta- } \\
\text { łości } \\
\text { The } \\
\text { highest } \\
\text { residue } \\
\text { level } \\
\text { (HR.P) } \\
\text { [mg/kg] }\end{array}$} & \multirow{3}{*}{$\begin{array}{c}\text { ARfD } \\
{[\mathrm{mg} / \mathrm{kg} / \mathrm{masy}} \\
\text { ciała] } \\
{\left[\begin{array}{c}\mathrm{mg} / \mathrm{kg} \text { body } \\
\text { weight }]\end{array}\right.}\end{array}$} & \multirow{3}{*}{$\begin{array}{c}\text { Współ- } \\
\text { czynnik } \\
\text { różno- } \\
\text { rodności } \\
\text { Variabi- } \\
\text { lity factor } \\
{[v]}\end{array}$} & \multirow{3}{*}{$\begin{array}{c}\text { Masa } \\
\text { jednostki } \\
\text { produktu } \\
\text { The weight } \\
\text { of first } \\
\text { commodity } \\
\text { unit (U) } \\
{[\mathrm{kg}]}\end{array}$} & \multicolumn{2}{|c|}{\begin{tabular}{|c|} 
Dane spożycia pełnej \\
porcji $(97,5$ percentyl $)$ \\
Full portion \\
consumption data \\
$(97.5$ percentile $)$ \\
\end{tabular}} & \multicolumn{4}{|c|}{ Pobranie - Intake } \\
\hline & & & & & & $\begin{array}{c}\text { dzieci } \\
\text { toddlers } \\
(14,5 \mathrm{~kg})\end{array}$ & $\begin{array}{l}\text { dorośli } \\
\text { adults } \\
\text { (76 kg) }\end{array}$ & \multicolumn{2}{|c|}{$\begin{array}{l}\text { dzieci - toddlers } \\
\quad(14,5 \mathrm{~kg})\end{array}$} & \multicolumn{2}{|c|}{$\begin{array}{l}\text { dorośli - adults } \\
\quad(76 \mathrm{~kg})\end{array}$} \\
\hline & & & & & & $\begin{array}{c}\text { [kg/osoba/ } \\
\text { dzień }] \\
{[\mathrm{kg} /} \\
\text { person/day }]\end{array}$ & $\begin{array}{c}\text { [kg/osoba/ } \\
\text { dzień }] \\
{[\mathrm{kg} /} \\
\text { person/day }]\end{array}$ & {$\left[\begin{array}{c}{[\mathrm{mg} / \mathrm{kg} / \mathrm{masy}} \\
\text { ciała }] \\
{\left[\begin{array}{c}\mathrm{mg} / \mathrm{kg} \text { body } \\
\text { weight }]\end{array}\right.}\end{array}\right.$} & $\begin{array}{c}\% \\
\text { ARfD }\end{array}$ & {$\left[\begin{array}{c}\mathrm{mg} / \mathrm{kg} / \mathrm{masy} \\
\text { ciała }] \\
{[\mathrm{mg} / \mathrm{kg} \text { body }} \\
\text { weight }]\end{array}\right.$} & $\begin{array}{c}\% \\
\text { ARfD }\end{array}$ \\
\hline $\begin{array}{l}\text { Papryka }^{2} \\
\text { Sweet } \\
\text { pepper }\end{array}$ & chlorothalonil & 0,09 & 0,6 & 7 & 0,160 & 0,0338 & 0,1433 & 0,001469 & 0,245 & 0,001188 & 0,198 \\
\hline \multirow{2}{*}{$\begin{array}{l}\text { Cebula } \\
\text { zielona }{ }^{1} \\
\text { Green } \\
\text { onion }\end{array}$} & chlorpyrifos & 0,01 & 0,1 & 1 & - & 0,0073 & 0,0534 & 0,000005 & 0,005 & 0,000007 & 0,007 \\
\hline & prometryn & 0,02 & 0,1 & 1 & - & 0,0073 & 0,0534 & 0,000010 & 0,010 & 0,000014 & 0,014 \\
\hline
\end{tabular}

ARfD - ostra dawka referencyjna - Acute Reference Dose

${ }^{1}$ oszacowanie narażenia krótkoterminowego na pozostałości ś.o.r. w warzywach uprawianych pod osłonami według wzoru (2) - risk assesment of the long-term exposure to pesticide residues in vegetables grown under covers according to the formula (2)

${ }^{2}$ oszacowanie narażenia krótkoterminowego na pozostałości ś.o.r. w warzywach uprawianych pod osłonami wedługg wzoru (3) - risk assesment of the long-term exposure to pesticide residues in vegetables grown under covers according to the formula (3)

ochrony, a skuteczność zastosowanych środków często decyduje o jakości i ilości zbiorów.

W tabeli 2. przedstawiono oszacowanie długoterminowego narażenia zdrowia ludzi w wyniku spożycia wszystkich wykrytych pozostałości ś.o.r. Najwyższe oszacowane długoterminowe narażenie konsumenta stwierdzono dla uprawy pomidora $\mathrm{w}$ grupie dorosłych $1,067 \%$ ADI, jak i dzieci - 2,033\% ADI. W przypadku spożycia innych warzyw uprawianych pod osłonami narażenie długoterminowe w obu grupach wiekowych nie przekraczało 0,967\% ADI. Po zsumowaniu wszystkich poszczególnych pobrań, co zwykle powoduje przeszacowanie uzyskanych wyników, narażenie długoterminowe $\mathrm{w}$ grupie ludzi dorosłych nie przekraczało $4 \%$, a w grupie dzieci $7 \%$.

Narażenie krótkoterminowe przedstawiono w tabeli 3 . Obliczono je dla s.cz. niezalecanych do ochrony danej uprawy, zakazanych do stosowania w ochronie roślin, jak i dla stwierdzonych przekroczeń. Wartości narażenia krótkoterminowego dla papryki wyniosły 0,245\% ARfD w grupie małych dzieci i $0,198 \%$ ARfD w grupie dorosłych, natomiast dla zielonej cebuli odpowiednio od 0,005 do $0,014 \%$ ARfD. W obu przypadkach są to wartości mocno odbiegające od dopuszczalnego progu $100 \%$.

$\mathrm{Na}$ podstawie przedstawionych wyników można stwierdzić, że warzywa uprawiane pod osłonami z terenu południowo-wschodniej Polski mogą być spożywane przez dzieci i dorosłych konsumentów zarówno jednorazowo, jak i w ciagu całego życia, bez powodowania niekorzystnych skutków zdrowotnych.

Oszacowane ryzyko narażenia długo- i krótkoterminowego przez pobieranie pozostałości ś.o.r. W warzywach uprawianych pod osłonami jest porównywalne $\mathrm{z}$ danymi otrzymanymi dla innych upraw (Nowacka i Gnusowski 2010; Nowacka i wsp. 2012a) i nie stanowi zagrożenia zdrowia konsumentów. Zdarzają się jednak przypadki incydentalne, wystąpienia zagrożenia dla zdrowia ludzi (Nowacka i Gnusowski 2009; Scientific Report of EFSA 2013), dlatego ważne jest, aby każdy z nich rozpatrywany był indywidualnie i natychmiast weryfikowany.

\section{Wnioski / Conclusions}

1. Najczęściej wykrywanymi substancjami w uprawach pod osłonami były pozostałości związków $\mathrm{z}$ grupy fungicydów.

2. Najwyższe oszacowane długoterminowe narażenie konsumenta stwierdzono dla uprawy pomidora w grupie dorosłych 1,067\% ADI, w grupie dzieci 2,033\% ADI. Po zsumowaniu wszystkich poszczególnych narażeń, narażenie długoterminowe w grupie ludzi dorosłych nie przekraczało 4\%, a w grupie dzieci 7\%.

3. Wartości narażenia krótkoterminowego w przypadku uprawy papryki wyniosły 0,245\% ARfD w grupie małych dzieci i 0,198\% ARfD w grupie dorosłych, a dla zielonej cebuli odpowiednio od 0,005 do 0,014\% ARfD.

4. Na podstawie stwierdzonych poziomów pozostałości ś.o.r. w analizowanych uprawach i po oszacowaniu narażenia zdrowia ludzkiego zarówno długo-, jak i krótkoterminowego można stwierdzić, że pobranie pozostałości ś.o.r. wraz z warzywami uprawianymi pod osłonami pochodzących $\mathrm{z}$ terenu południowo-wschodniej Polski nie stanowiło zagrożenia zdrowia konsumentów. 


\section{Literatura / References}

Chmiel Z. 1979. Spektrofotometryczne oznaczanie śladowych pozostałości dwutiokarbaminianów w materiale roślinnym. Chem. Anal. 24: 505-512.

Document SANCO/10684/2011. 2011. Method validation and quality control procedures for pesticide residues analysis in food and feed, $40 \mathrm{pp}$.

Główny Urząd Statystyczny. 2011. Rocznik statystyczny rolnictwa. Zakład Wydawnictw Statystycznych, Warszawa, 393 ss.

Góralczyk K., Ludwicki J.K., Czaja K., Struciński P. 1998. Monitoring pozostałości pestycydów w żywności w Polsce. Rocz. PZH 49: 331-339.

Grzegorzak M., Szpyrka E., Słowik-Borowiec M., Kurdziel A., Matyaszek A., Rupar J. 2012. Potential risk to consumer related with occurrence of pesticide residues in early vegetables. Ecol. Chem. Eng. A, 19 (3): 239-248. DOI: 10.2428/ecea.2012.19(03)025.

Kostka G., Urbanek-Olejnik K., Liszewska M. 2011. Szacowanie ryzyka dla łącznego narażenia na pozostałości pestycydów w żywności. Rocz. PZH 62: 127-136.

Łozowicka B. 2010. Studium nad pozostałościami środków ochrony roślin w płodach rolnych północno-wschodniej Polski. Rozpr. Nauk. Inst. Ochr. Roślin - PIB, Poznań 21, 177 ss.

Nowacka A., Gnusowski B. 2009. Bezpieczeństwo zdrowotne polskich płodów rolnych w aspekcie pozostałości środków ochrony roślin stosowanych do ich ochrony. [Estimation of dietary exposure to pesticide residues in polish crops in 2008]. Prog. Plant Prot./Post. Ochr. Roślin 49 (4): 1895-1902.

Nowacka A., Gnusowski B. 2010. Ocena ryzyka zagrożenia zdrowia ludzi pozostałościami środków ochrony roślin w polskich płodach rolnych w roku 2009. [Estimation of dietary exposure to pesticide residues in polish crops in 2009]. Prog. Plant Prot./Post. Ochr. Roślin 50 (4): 1938-1946.

Nowacka A., Gnusowski B., Walorczyk S., Drożdżyński D., Raczkowski M., Hołodyńska A., Frąckowiak D., Wójcik A., Ziółkowski A., Rzeszutko U., Domańska I., Jurys J., Łozowicka B., Kaczyński P., Rutkowska E., Jankowska M., Hrynko I., Szpyrka E., Rupar J., Rogozińska K., Kurdziel A., Słowik-Borowiec M., Michel M., Kuźmenko A., Szala J. 2011. Pozostałości środków ochrony roślin w płodach rolnych (rok 2010). [Pesticide residues in polish crops (2010)]. Prog. Plant Prot./Post. Ochr. Roślin 51 (4): $1723-1738$.

Nowacka A., Gnusowski B., Raczkowski M. 2012a. Bezpieczeństwo zdrowotne polskich płodów rolnych w 2010 roku związane z pozostałościami środków ochrony roślin. [Estimation of dietary exposure to pesticide residues in Polish crops in 2010]. Prog. Plant Prot./Post. Ochr. Roślin 52 (1): 141-145.

Nowacka A., Gnusowski B., Walorczyk S., Drożdżyński D., Raczkowski M., Hołodyńska A., Frąckowiak D., Wójcik A., Ziółkowski A., Przewoźniak M., Swoboda W., Rzeszutko U., Domańska I., Jurys J., Lozowicka B., Kaczyński P., Rutkowska E., Jankowska M., Hrynko I., Szpyrka E., Rupar J., Rogozińska K., Kurdziel A., Słowik-Borowiec M., Szala J., Szponik M., Michel M. $2012 b$. Pozostałości środków ochrony roślin w płodach rolnych (rok 2011). [Pesticide residues in Polish crops (2011)]. Prog. Plant Prot./Post. Ochr. Roślin 52 (4): 1107-1116.

Pesticides Safety Directorate. New intake calculation models for consumer intake assessments. 2006. http://www.pesticides.gov.uk/ guidance/industries/pesticides/topics/pesticide-approvals/pesticides-registration/data-requirements-handbook/uk-consumer-intakemodels, accessed: 03.12.2012.

PN-EN ISO/IEC 17025. 2005. Ogólne wymagania dotyczące kompetencji laboratoriów badawczych i wzorcujących. PKN, Warszawa, 42 ss.

Rozporządzenie 396/2005 Parlamentu Europejskiego i Rady z dnia 23 lutego 2005 r. w sprawie najwyższych dopuszczalnych poziomów pozostałości pestycydów w żywności i paszy pochodzenia roślinnego i zwierzęcego oraz na ich powierzchni, zmieniające dyrektywę Rady 91/414/EWG (Dz. Urz. L 70, str. 1 z 16.03.2005 r. z późn. zm.).

Rozporządzenie Ministra Zdrowia z dnia 17 października 2007 r. w sprawie pobierania próbek żywności w celu oznaczania poziomów pozostałości pestycydów. 2007. Dz. U. nr 207, poz. 1502, 2007.

Sadło S., Szpyrka E., Rogozińska K., Rupar J. 2003. Oznaczanie pozostałości ditiokarbaminianów w owocach i warzywach na poziomie $0,01 \mathrm{mg} / \mathrm{kg}$. [Determination of dithiocarbamate residues in fruit and vegetables at the level of $0.01 \mathrm{mg} / \mathrm{kg}$ ]. Prog. Plant Prot./Post. Ochr. Roślin 43 (2): 895-897.

Scientific Report of EFSA. 2013. The 2010 European Union report on pesticide residues in food. EFSA J. 11 (3): 30-31, 209 pp. DOI: 10.2903/j.efsa.2013.3130.

Zalecenia Ochrony Roślin na lata 2010/2011. Cz. III. Warzywa, Sady. 2010. Inst. Ochr. Roślin - PIB, Poznań, 228 ss.

Zalecenia Ochrony Roślin na lata 2012/2013. Cz. III. Warzywa, Sady. 2012. Inst. Ochr. Roślin - PIB Poznań, 219 ss. 